Vol. I No. 2 - August 2020

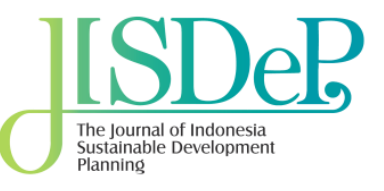

E-ISSN: 2722-0842 | P-ISSN: $\underline{\text { 2721-8309 }}$

Available online at

http://journal.pusbindiklatren.bappenas.go.id/

Kementerian PPN/

Bappenas

\title{
Strengthening Community Economy Inclusively through Literacy for Prosperity
}

\section{National Library of Indonesia's Role to Support Sustainable Development Goals (SDGs)}

\author{
Reza Mahdi \\ Faculty of Letters, State University of Malang, Malang, \\ Indonesia \\ rezamahdi2@gmail.com
}

\begin{abstract}
The term literacy continues to evolve from time to time according to the conditions of a society. At first, UNESCO in 1997 concluded that literacy is the ability to identify, understand, interpret, communicate, and count using printed or other materials, but the meaning of literacy is much more than that, which in the end a literate community can produce something that is beneficial to individuals or society. Therefore, the prosperity of a society can be seen from the number of literate people. National Library of Indonesia has recorded it in the concept of literacy for prosperity in the Social Inclusion-Based Library Transformation program. One of the programs carried out is for the prosperity of the literacybased economic community that also aims to support SDGs. Until now, the National Library of Indonesia has succeeded in bringing about a positive impact on the community's economy with the concept of as well as support for SDGs. In the future, there are still many things that must be researched by the National Library of the Republic of Indonesia regarding literacy for inclusive prosperity.
\end{abstract}

Keywords: literacy; social inclusion; SDGs; economy

ARTICLE INFO
Received: June 16, 2020
Received in revised form: August 20,
2020
Accepted: August 26, 2020

doi: $10.46456 /$ jisdep.v1i2.62
JISDeP - The Journal of Indonesia Sustainable Development Planning Published by Centre for Planners' Development, Education, and Training (Pusbindiklatren),

Ministry of National Development

Planning/ National Development

Planning Agency (Bappenas), Republic

of Indonesia
Address: Jalan Proklamasi 70,

Central Jakarta, Indonesia 10320

Phone: +62 $2131928280 / 3192828$

Fax: +62 2131928281

E-mail: pusbindiklatren@bappenas.go.id

Supported by Indonesian Development Planners Association (PPPI) 


\section{Introduction}

The term literacy is a term that has been widely recognized by the community. Many of these terms are used by the community in making or conducting an activity. For example, health literacy is the capability of being critical of existing health information and practicing it properly. Then there is another term, financial literacy, which is knowledge of improving financial prosperity so that people can make good financial decisions. Literacy essentially means the ability of a community or individual to write or read. UNESCO in 1997 says that literacy is the ability to identify, understand, interpret, create, communicate, and count using printed materials or other writings in various contexts (Montoya, 2018).

Now, the paradigm of literacy is not only about reading and writing, but can also be about knowledge or skills for people to live in society. It is also associated with accessing digital information and using it well by looking at Bloom's Taxonomy, namely remembering, understanding, applying, analyzing, evaluating, and creating. In this 21st century, the definition of literacy has also led to the ability to use technology to use and disseminate information (Pilgrim \& Martinez, 2013).

The Australian Literacy Educators Association (ALEA) also stated in 2015 that literacy has a strong definition of Life Skills beyond traditional speaking, listening, reading, and writing. In Australia, one of the literacy capabilities of the community is to be able to respond well and produce important social, cultural, aesthetic, historical, and economic works. Then, what about in Indonesia? Minister of Education and Culture in 2019, Muhadjir Effendi also said so. Reported from Pikiran Rakyat news portal, literacy starts from reading, but then makes something good. The process occurs continuously throughout life (Seftiawan, 2019). The point is that literacy is a process of society that can eventually be creative for the benefit of itself and society, after reading. Actually, it is not only from reading, but also from the information that we are able to capture from a workshop.

Regarding literacy, a community can be prosperous if many people are literate. The Journal-Advocate in Sterling (2016) also argues that the point is not just a person, but a whole community. There is no doubt that a literate (at least able to read and write) society is prosperous. Yes, it is true that the ability to read comprehensively and to write smoothly is the key to progress, in addition to understanding the meaning of the reading and being critical. Apart from reading to increase literacy, education to develop community skills can also support prosperity in social and economic aspects. One of the institutions that plays a role in the development of literacy in community is the library, especially the public library. The public library is a lifelong learning facility for the general public regardless of who they are (Sumekar et al., 2011).

In 2018, the National Library of Indonesia executed the concept of strengthening literacy for prosperity that until now is in its national priority program, Transformation of Social Inclusion-Based Library. The concept is to revitalize the function of public libraries in order to become the center of community activities, ultimately leading to community empowerment. Firstly, it was the concept of Coca-Cola Foundation's program, Perpuseru, in 2017 where they revitalized the many functions of public and village libraries. Then in 2018, Coca-Cola Foundation released its concept to the National Library of Indonesia (Yamin, 2018). Finally, by 2019, literacy for prosperity had become a national priority.

Literacy here is not only limited to reading and writing, but is more about how people empower public libraries with all the information and activities organized by them. If viewed, one of the conceptual directions is strengthening the community economy inclusively. An example of this is vocational skills training organized by a public Library that became a conceptual partner of the National Library of the Republic of Indonesia to encourage the community to create business. In the end, the concept supports the empowerment of small and medium enterprises (SMES) so that the community is ensured to be economically prosperous.

The word 'inclusively' refers to social inclusion that has a meaning to enhance the dignity and opportunity of the community or individuals to participate in society regardless of the reeds. Participation is carried out in accordance with the roles the people play. Actually, the concept of social inclusion is carried out to end poverty according to the first concept introduced by Leonir, a French Politician. He put forward the concept of social inclusion in 1975 in Paris during prosperity (Warsilah, 2015). Social inclusion itself appeared after the social exclusion phenomenon, which means the inability of an individual or a group of community to join other communities. 
Back to social inclusion, Leonir's idea was then used by the European Union to end poverty in 1975, because the term 'poverty' in that year shifted into 'exclusion' (Rawal, 2008). The concept of social inclusion is currently used to resolve various social problems besides economic problems, but it is still related to efforts to ensure economic prosperity for all levels of society. From this explanation, literacy for prosperity is related to the concept, because the concept leads to community empowerment to be prosperous, but social inclusion places greater emphasis on the potential for exclusion of people such as poor communities.

Strengthening the concept of literacy for prosperity is also to support the Sustainable Development Goals (SDGs) as a national priority that has previously been mentioned. With regard to libraries and the SDGs, IFLA, an organization that coordinates SDGs library support nationwide, has a target that as many as 320,000 libraries in the world, such as national, general, university, school, and special libraries will be regarded as one of the most important organizations because they provide information for all groups of people (IFLA, 2016a). A wide variety of libraries in countries around the world support SDGs in different ways that can be seen on the IFLA website (https://librarymap.ifla.org/stories).

Support from the National Library of Indonesia for SDGs was initially based on the participation of representatives from Indonesia to join the International Advocacy Programme (IAP): SDGs from October 31 to November 1, 2016, on the National Library Board (V-floor), Victoria Street 1401 Singapore. The objectives of the workshop are (1) to provide training and advocacy so that libraries can align their programs with SDGs and (2) to ensure that every library around the world can implement its programs in the national sustainable development agenda. The National Library of Indonesia officially supports the SDGs after the government issued Presidential Regulation Number 59 Year 2017 concerning SDGs (Peraturan Presiden No.59 tahun 2017 tentang Tujuan Pembangunan Berkelanjutan).

The concept of literacy for prosperity is supported by the Ministry of National Development Planning or the National Development Planning Agency (BAPPENAS) as the institution that is responsible for the course of SDGs in Indonesia. Until now, the National Library of the Republic of Indonesia continues to develop the function of public libraries in all provinces in Indonesia with the concept that the community can prosper with the existence of a public library as one of the economic sectors. The National Library of the Republic of Indonesia continues to innovate and collaborate in the context of creating a prosperous literacy society.

The purpose of this study is to learn more about literacy and the impact of community prosperity, especially in economic aspect. This has certainly seen a change in the paradigm of literacy from time to time that is only the ability to read and write but is more than that. In addition, the next goal is to learn more about library programs in support of SDGs according to their roles. Considering that SDGs is a national priority, this research was conducted at the National Library of Indonesia.

\section{Research Method}

The type of research in this paper is qualitative research that is the presentation of data in the form of narratives as well as images from documentation and interviews. The examined aspects are also subjective, namely from the customs or culture of the society (Connaway \& Powell, 2010). The method used is a case study, meaning the use of various data sources to study individuals, institutions, or phenomena such as events or programs in a unique environment in an intense and detailed manner (Hariwijaya, 2016; Lawal, 2009).

\subsection{Concept}

As explained in the research background, the current concept of literacy is closely related to social inclusion-based libraries, especially public libraries. The concept of the research can be seen in Figure 1 below.

The definition of literacy is essentially proficient in reading and writing, as explained earlier. But over time, the understanding of literacy has also developed. In addition to being proficient in reading and writing, literate communities are able to create and perform activities that make them empowered. Meanwhile, the concept of social inclusion aims to empower all levels of society, which are related to literacy because both of them aim at community empowerment. 
(Sterling Journal Advocate, 2016).

(ALEA, 2015)

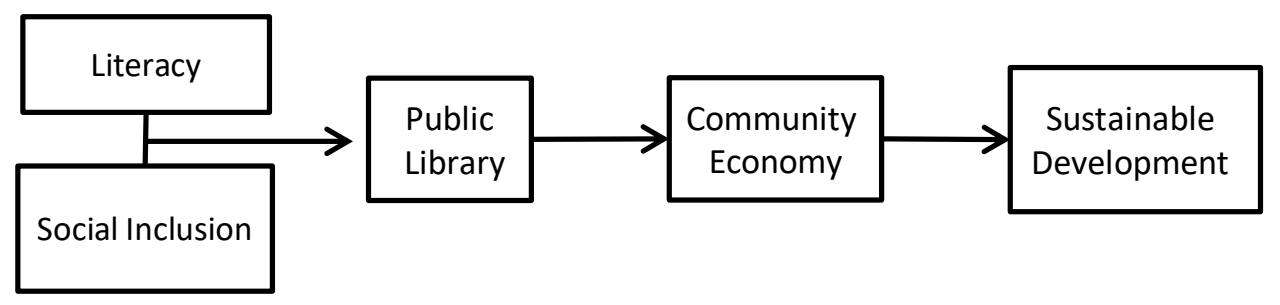

(UNDESA, 2016)

Figure 1: Research concept

Social inclusion means building the community to be open to others, increasing participation in society, especially for those who are potential to be excluded, through increasing opportunities, access to resources, and respect for them (UNDESA, 2016). Potentially excluded societies can be seen in terms of age, gender, disability, race, ethnicity, origin, religion, or economic status or others. Therefore, empowerment can be done to them to increase their confidence in interacting with the community

Empowerment towards them can later encourage social interaction between communities in opening access to participation in all areas of social life (Silver, 2015). Furthermore, empowerment can also be carried out to them based on literacy, for example through reading or accessing information then following training so that they can be empowered. Literacy is not only reading but also being able to receive information from other people and understand it so that in the future they can create something, said Effendi in his research background.

Then, public libraries are the most important institution in realizing a literate community for life. They play an important role in developing the potential of communities by providing access to various knowledge, ideas, and opinions contained therein (IFLA, 2010). Thus, the provision of collections should reflect the conditions of the surrounding society and the procurement of collections must also receive requests from the community. For example, people who want to practice planting plant ask the public library to procure related books. After the books are available, people start to access them by reading on the spot or borrowing them to read at home. Later, they do not just practice and develop interest in reading, but they can also get inspired and create something good.

Related to creation, public libraries as a means of lifelong learning are certainly not only used for reading, but also used for developing learning skills. Public libraries can be utilized by the community as an activity space to create something good or as a makerspace (Safira, 2019). This can also be done by holding public library events in collaboration with other communities to carry out activities in the library. This literacy-based empowerment is also conducted with the concept of social inclusion, considering that public libraries are open to all levels of society. There is no difference in accessing public libraries in terms of race, religion, ethnicity, physical condition, and social and economic status. The libraries are ensured to hold skills training activities that pay attention to community's participation.

People will later think that the library is a good place to accommodate anyone because they believe in the benefits of its existence, so that there will be community confidence that the library is a place for everyone, no one is excluded (Adyannisa \& Laksmi, 2018; Vårheim, Steinmo, \& Ide, 2008). This will in turn increase community participation in public libraries, both for those who are potentially marginalized and for the general public.

The Head of BAPPENAS for the 2016-2019 period, Bambang P.S. Brodjonegoro, presented the topic of society building with literacy in the 2018 National Seminar on Literacy and Socio-Economic Development. He said that education and literacy are part of human development that can pave the way for breaking 
the chain of poverty in community (Afandi, 2018). This means strengthening literacy for prosperity in public libraries can build the community's economy.

Ultimately, these will all lead to sustainable community development. When many people are literate, the next literate community will be born. Therefore, the concept of literacy with social inclusion is implemented in public libraries, which in turn embodies literacy for prosperity for the sake of strengthening the community's economy that leads to sustainable development.

\subsection{Data Collection}

Data collection techniques in this research were carried out by interviews and documentation. An interview is an activity in which two or more people meet to exchange information and ideas through questions and answers so that they can form the meaning of an existing problem or topic (Sugiyono, 2009). An interview can be done in a semi-structured manner by following existing guidelines but can be revised as new ideas arise (Rachmawati, 2007).

The interview was conducted with J.S, the Head of National Library Law and Planning Bureau, who conceptualized the social Inclusion based library transformation program after being released by PerpuSeru to the National Library of Indonesia. Then, the next interviewee was S.S, the Main Secretary of the National Library of Indonesia, who had participated in the training of SDGs held by IFLA in 2016 in Singapore. Then the supporting resource was A.M. from the Magelang Regency Public Library who was the social inclusion PIC there. The Public Library of Magelang Regency has been ranked $2^{\text {nd }}$ most inclusive regional public library in Indonesia.

The next data retrieval used the documentation method, that is investigating written objects such as books, magazines, regulatory documents, meeting notes, etc (Mamik, 2015). Furthermore, in this developing era, documentation can also be done by investigating information that is electronic in nature. Therefore, retrieving data that is on the Internet is also a documentation (Mustafa, 2013). Documents are generally data that strengthen qualitative research, because they can be evidence of information conveyed by informants or obtained when making observations.

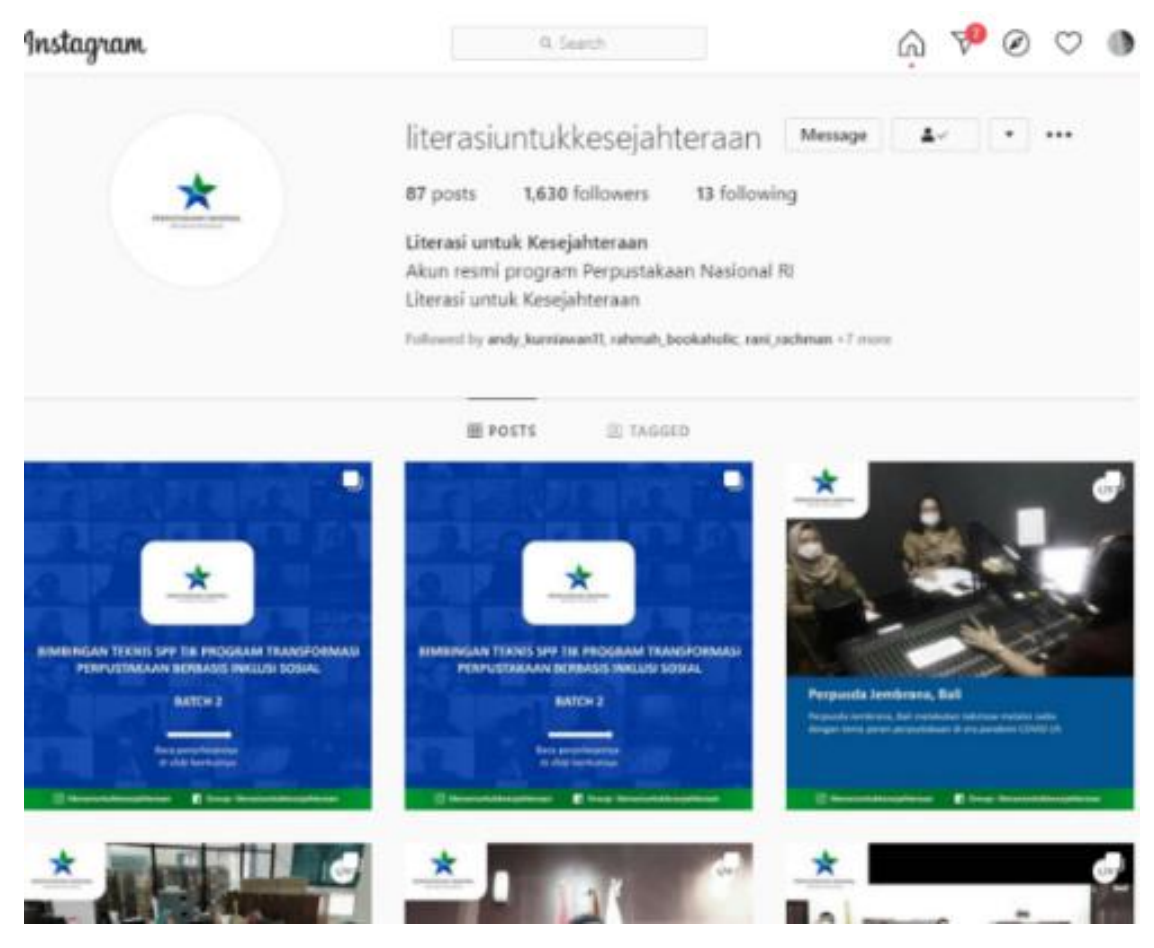

Figure 2: Instagram account of Literasi Untuk Kesejahteraan (@literasiuntukkesejahteraan) 
Therefore, this research analyzes the documents provided by the National Library of the Republic of Indonesia regarding the implementation of the concept of literacy for prosperity. In addition to documents from the National Library of the Republic of Indonesia, an analysis was also conducted on documents from the public libraries in partnership with the Transformation of Social Inclusion-Based Library that has implemented the concept of literacy for welfare. Information documents were also obtained from social media, Instagram account, Literacy for Prosperity (@literasiuntukkesejahteraan) which is the media for the National Library of the Republic of Indonesia to promote the impacts received by the community.

Then related to the SDGs, the results of the analysis of the documents and interviews on literacy for prosperity will be attributed to the points in the SDGs, especially in the economic aspect as discussed here, namely the economic empowerment of the community. This refers to the formulation established by the UN in 2015 and IFLA in 2016.

\section{Literacy for Prosperity: Strengthening Community Economy}

The concept of literacy for prosperity is the impact of literacy paradigm change itself in accordance with the times. The community will be empowered, one of which is from an economic standpoint after they read or participate in activities that are organized by the library. Until now, this has been the focus of the National Library of the Republic of Indonesia in establishing a literate and prosperous community with the existence of libraries. National Library of Indonesia builds public libraries in Indonesia based on social inclusion, so that the community can be economically empowered with the existence of public libraries.

To implement this concept, the National Library of the Republic of Indonesia is in collaboration with government and non-governmental institutions. The institutions that work together include BAPPENAS, the Regional Development Planning Board (BAPEDA), the Community and Village Empowerment Offices, the Offices of Communication and Informatics, the Offices of Industry and Trade, and others such as, private sectors, universities, NGOs/civil society/community organizations, private companies, mass media.

The concept of literacy for prosperity is accepted by public libraries in various regions/cities in developing their services to become the center of community activities. Until now, according to data provided by the National Library of the Republic of Indonesia, as many as 1,050 public libraries in 21 provinces, 59 districts, and 500 villages have implemented the concept of literacy for prosperity. The implementation of the concept has a good impact on the prosperity of society from an economic perspective; for example, many people end up opening a business or upgrading it after attending some workshops or reading the collections that are provided by public libraries.

Regarding collections that can empower the community's economy, there is a success story of a person named Suprayetno. From the information that has been collected from the National Library of Indonesia reports, he is a citizen of Sekip village, Deli Serdang Regency that has been running an ornamental fish business since 2007, but has not had a large turnover and profit because he runs it traditionally. Finally, after Sekip Village library was revitalized with the concept of literacy for prosperity, Suprayetno could directly access a collection about ornamental fish cultivation.

Since he was diligent in reading the book and practicing the cultivation techniques written in the book, Suprayetno succeeded in boosting the turnover of his business. Now with the information in the book he borrowed from the village library, he makes his own fish feed. The fish feed manufacturing business itself is able to reduce the cost of fish production/maintenance which in itself gives additional benefits from the green fish business.

Another success story was experienced by Ariadati, who opened an oyster mushroom business after she read in her village library. She tried the business to help with her family's income because her husband just worked as a security guard. With initial capital obtained from a Village-owned Enterprise (Bumdes) and knowledge that she got from reading in Bener Meriah Village Library, Aceh Province, she managed to open a business of crispy oyster mushroom that helped her family's income. Initially, she got the idea after seeing that not all of the mushrooms that had just been harvested could be sold to the market so that they became leftovers. She wanted to turn the leftovers into snacks that most people liked. 


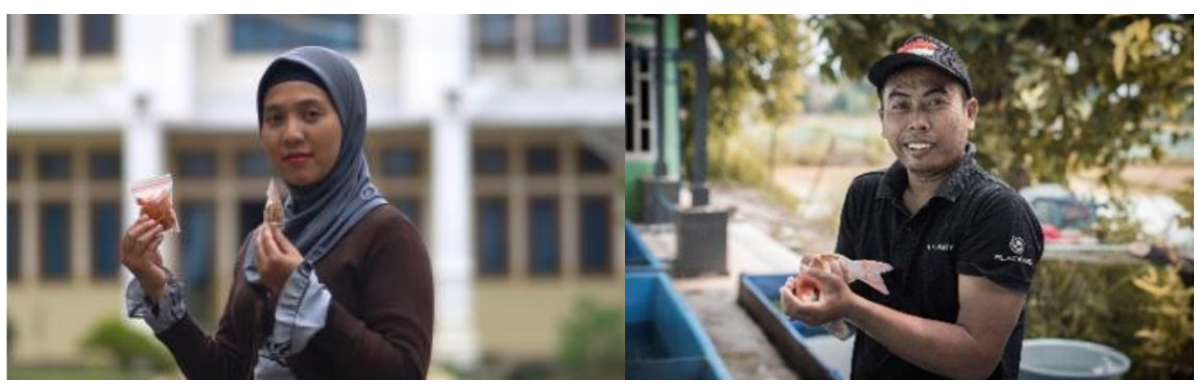

Figure 3. Ariadati (left) and Suprayetni (Right) (National Library of Indonesia Report 2019-2020)

These two phenomena are examples of the strengthening of a literacy-based economy, from reading to applying the recitation and finally improving living standards. In addition, it will also be able to change the paradigm of the current public libraries of counties/towns and villages. The following was narrated by J.S. as the head of the Legal and Planning Bureau, National Library the Republic of Indonesia.

"The literacy for prosperity will change the paradigm of public libraries in the community. People think libraries are just for writing a thesis or reading, but actually more than that. Public libraries must carry out literacy-based community empowerment activities. "

The narrative of J. S means that today's public libraries do not only provide a means of reading but also self-development. It is also in accordance with regulations in Indonesia that public libraries are places for lifelong learning (Sumekar et al., 2011), which also has the meaning of learning and practicing from the books that we read. IFLA (2010) also writes that public libraries provide knowledge and ideas to the community, so that they can lead to the development of educational skills.

Then after adapting the concept of literacy for prosperity, public libraries organized a lot of community empowerment activities. Below are two tables of the top 10 total community empowerment activities in public libraries that implemented literacy for prosperity, during the year 2019.

Table 1. Top 10 Total Activities of City / Regency Public Libraries for community engagement, as of 9 December 2019 (National Library of Indonesia Report)

\begin{tabular}{llc}
\hline \multicolumn{1}{c}{ Province } & \multicolumn{1}{c}{ Region } & Total of Activities \\
\hline Central Java & Magelang & 385 \\
South Sumatera & Musi Banyuasin & 190 \\
Central Kalimantan & Sukamara & 188 \\
\hline North Sumatera & Deli Serdang & 168 \\
\hline North Sumatera & Labuhanbatu & 149 \\
Riau & Siak & 142 \\
Aceh & Aceh Tengah & 117 \\
West Nusa Tenggara & Bima & 113 \\
\hline South Sumatera & Musi Rawas & 98 \\
West Kalimantan & Landak & 82 \\
\hline
\end{tabular}

Table 2. Top 10 Total Activities of Village Library for community engagement, as of 9 December 2019 (National Library of Indonesia Report)

\begin{tabular}{llc}
\hline \multicolumn{1}{c}{ Region } & \multicolumn{1}{c}{ Village } & Total of Activities \\
\hline Tulang Bawang & Dwimulyo & 290 \\
Batang Hari & Bukit Harapan & 220 \\
Musi Banyuasin & Bukit Jaya & 195 \\
\hline
\end{tabular}




\begin{tabular}{lll}
\hline Kotawaringin Timur & Bagendang Permai & 162 \\
Labuhanbatu & Kampung Baru & 151 \\
Soppeng & Tellulimpoe & 130 \\
Serdang Bedagai & Rambung Sialang Tengah & 130 \\
Brebes & Dawuhan & 126 \\
Deli Serdang & Sekip & 125 \\
Sukamara & Lupu Percua & 111 \\
\hline
\end{tabular}

The two tables above show that within a year many libraries continued to hold activities that involved the community there leading to community empowerment. Regarding Community Empowerment, J. S continued his statements as follows.

"In the Public Library of Pamekasan Region, there is a librarian who also works as a farmer, so that he gives books that are agriculture-related to farmers, but not only books; he has also brought experts from the Agriculture Agency to train the farmers as well. As a result, there is collaboration between librarians, farmers, and related agencies. "

It can be concluded from his statement that the public library of Pamekasan Regency, Madura, East Java, which is a partner of the concept of literacy for prosperity, has created a program for farmers. Here, there is collaboration between librarians, farmers, and the agriculture agency to provide agricultural knowledge and skills. In essence, the program has brought back the collaboration between organizations and communities.

Various kinds of community empowerment activities have been conducted by public libraries that implement the concept of literacy of prosperity, in collaboration with other communities or organizations. For example, in Central Java, the Public Library of Magelang Regency has carried out craft training activities for women. A.M, the PIC of Social Inclusion program at the Public Library of Magelang Regency said the following,

“...We also facilitate women according to their needs, to improve their family's economy. They asked for training on making craft from purr ropes. It had 20 people at first but then 33 people in total. We are in cooperation with Magic Hand community. The impact can already be seen, which can increase family's income..."

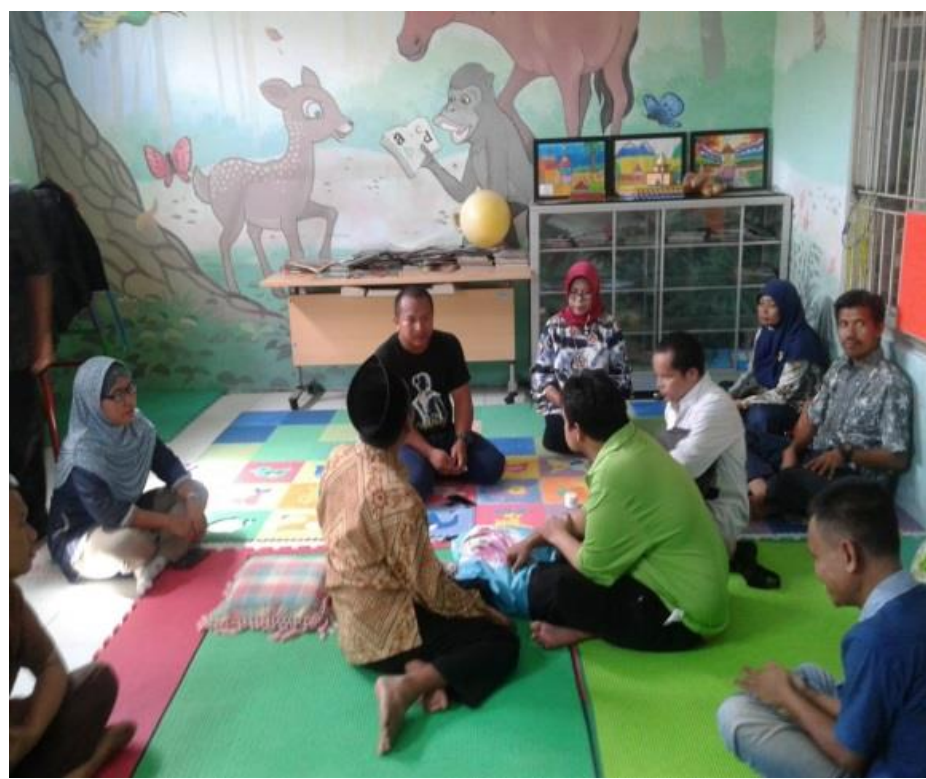

Figure 4. Massage Workshop for Blind People in Public Library of Kendal Regency (Public Library of Kendal Regency Report, 2019) 
Therefore, the training, the activities of which were from creating to marketing the products, partnered with members of the Magic Hand community as resource persons. As a result, their economic condition was helped. In addition, A.M. also said that the library was also concerned with and facilitated the disabled according to their needs. They wanted to learn resin processing and this could lead to a new business.

A workshop to improve the economy of the disabled was also conducted by the Public Library of Kendal District, Central Java. Based on the report, the library, in collaboration with DPC Pertuni, a social organization that empowers the blind, carried out massage training for the blind. In the end, because of the training, many participants of the training successfully opened blind massage services, which helped their economy.

One example of an Indonesian citizen who got the benefits is Imam who is blind, with his blind wife and his normal daughter. He managed to open a massage clinic that he named "Anugrah". Based on the National Library of Indonesia's report, this can be done thanks to the massage training organized by the Public Library of Kendal Regency that he participated in. In one day, he can get 3-6 customers that can make his family better and can meet their daily needs.

In Ponorogo, East Java, there is an online entrepreneurship training organized by the Library and Archives Office of Ponorogo Regency in collaboration with the Ponorogo Bukalapak Community. In addition to empowering the community's economy, this is also in line with the times, because ecommerce is commonplace in today's digital era. Then, there is another skill training for women, a workshop on recycling plastic bags to make a variety of flower arrangements. This activity aims to increase public awareness to be more prudent in the use of plastic bags, and to be more capable of utilizing plastic waste to become items that have sale value.

Community economic empowerment with the concept of literacy for prosperity also takes into account the potential assets that exist in the surrounding environment, so as to increase productivity. In Sodong Village Library, Tangerang Regency, Banten Province, there have been instant ginger-making training activities for the community, especially for women, with tutors who are experts in these activities. Not only that, there was a training on making PVC pipes to be used as ornaments, attended by 5 young people. This is based on research collections in the library. One of the persons who has benefited from this concept is Deni Anggara (30 years old), a layoff victim.

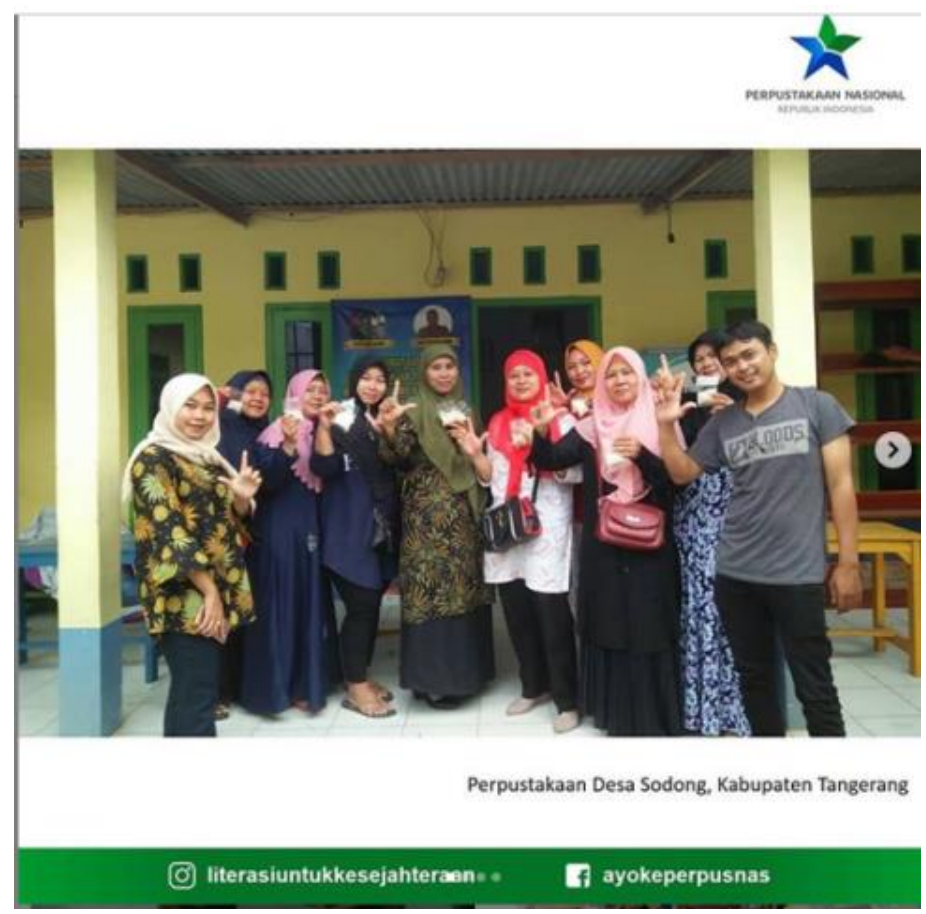

Figure 6. Training activities for women at Sodong Village Library (Literasi Untuk Kesejahteraan Instagram, 2019) 
Based on the National Library of Indonesia's report, he tried to find business opportunities to support his family after layoff. With the intention of utilizing used pipes in his environment, Deni then participated in a training on making ornamental lamps made of pipes, which was organized by Karang Harum Village Library. As a result, he ventured to open an ornamental lamp making business by selling directly and through social media. For two months after the training, Deni received orders of 40 pieces with a turnover of Rp.4 million. He also continues to practice his skills by learning more models of ornamental lamps through YouTube and in the future, he will expand his business to create decorative lamps for brides.

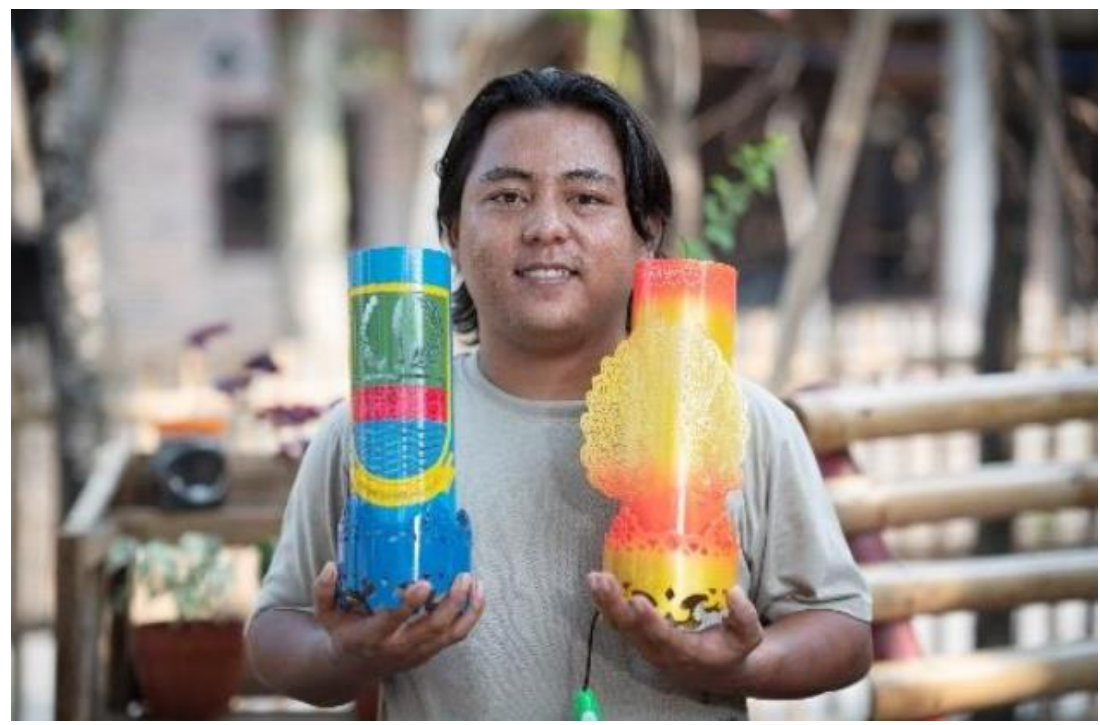

Figure 7. Deni Anggara with his ornamental lamp, created from paralon pipes (National Library of Indonesia Report 2019-2020)

Then, another example from outside Java is purun (a swamp plant) craft training at the library of Lupu Peruca village, Sukamara, Central Kalimantan. Purun is a local asset in Central Kalimantan, because since then the society has been processing purun into bags, mats, hats, and baskets. Based on the National Library of Indonesia's report, the head of the village supports the activities that exist in the village and promotes regional potential assets owned by the community and increases the village library budget; hence, the training of purun crafts, which is a local asset, was carried out in the village.

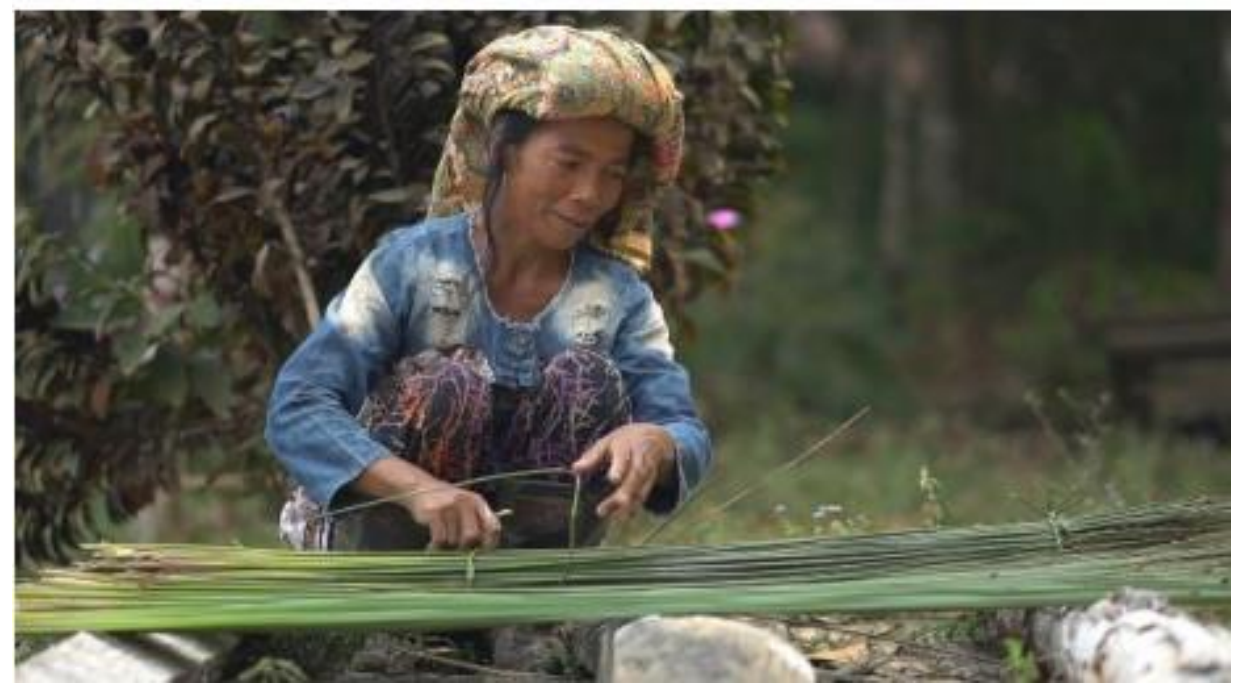

Figure 8. Mrs. Inor is processing purun (National Library of Indonesia Report 2019-2020) 
Mrs. Inor (51 years old) is one of the citizens of the village that cooperated with the library to conduct a purun crafts making workshop to produce bags, mats, etc. She wanted to train herself and other women in the village to create something from purun. Mrs. Inor's activities at the village library went well so that many people in Sukamara Village ordered her creation. As a result, Mrs. Inor's income increased, and so the income of other women who participated in making purun crafts, through orders from the Sukamara community.

Those phenomena are the results of implementing the concept of literacy for prosperity, other examples of which can be seen on the official Instagram account that is managed by the National Library of the Republic of Indonesia, @literasiuntukkesejahteraan (Literasi Untuk Kesejahteraan). The National Library of Indonesia has succeeded in stimulating the growth of community's economy by developing public library services as a center for literacy-based community activities. In the end, public libraries are not considered as eyes, which so far have only been a ' warehouse for books' but have made the community economically literate and empowered.

For the welfare of the community's economy, the National Library of Indonesia collaborates with several organizations, such as unions, investment services, institutions, and Micro, Small and Medium Enterprises (UMKM), to provide assistance such as capital and workshops. Other organizations, such as regional owned enterprises (BUMD) and BUMDES, also provide assistance such as the example in Bener Meriah Village as previously mentioned.

\section{Supporting the Economic Pillar of Sustainable Development Goals}

The concept of literacy for prosperity in the Transformation of Social Inclusion-Based Library program is also run by the National Library of the Republic of Indonesia to support the Sustainable Development Goals. In RPJMN 2020 - 2024 compiled by BAPPENAS, one of the supports for the development of culture and national character is increasing cultural literacy and developing library services based on social inclusion (Bappenas, 2019). Regarding this matter, the Main Secretary of the National Library of the Republic of Indonesia, S.S. said the following.

"Strengthening literacy for prosperity is supported by BAPPENAS. This is implemented to support SDGs program in particular for Goal 1, No Poverty; Goal 3, Good health and well-being; and Goal 4, Quality Education. This is implemented through the Transformation of Social Inclusion-Based Libraries. "

In the quotes above, S.S. stated that strengthening literacy for prosperity supports three goals of the SDGs but not from the economic pillar. The three goals that she mentioned fall under the social pillar. Literacy for prosperity certainly supports goals 1 and 4, and indirectly supports goal 3, but it also supports many other goals in the economic pillar.

In the economic pillar of the Sustainable Development Goals, there are 4 goals that fall under the pillar. The goals are goal 7 (Affordable and Clean Energy), 8 (Decent Work and Economic Growth), 10 (Reduced Inequalities), and 17 (Partnership for Goals). However, after a review, the National Library of the Republic of Indonesia's support to SDGs through strengthening literacy for prosperity further leads to goals 8,10 , and 17 . Only a few indicators from the economic pillar that are supported by the National Library of Indonesia. The following is the review of the indicators.

Literacy for Prosperity and its support to Economy Pillar of Sustainable Development Goals

UN Indicator(s) (2015) IFLA Indicator(s) (2016b) Explanation

\section{Goal 8. Decent Work and Economic Growth}

Indicator 8.3 - Promoting development policies that support productive activities, decent job creation, creativity and
Access to information and training skills that people need to find, apply for a job, and succeed in a better job
The impact of the concept implementation by the National Library of Indonesia is the emergence of entrepreneurial activities derived from 


\begin{tabular}{|c|c|}
\hline $\begin{array}{l}\text { innovation, and } \\
\text { entrepreneurship, and } \\
\text { encouraging the } \\
\text { formalization and growth of } \\
\text { micro, small, and medium } \\
\text { enterprises, including } \\
\text { through access to financial } \\
\text { services. }\end{array}$ & $\begin{array}{l}\text { workshops by public libraries } \\
\text { post the revitalization with that } \\
\text { concept. For example, the } \\
\text { workshop that was held by the } \\
\text { Public Library of Magelang } \\
\text { Regency made most of the } \\
\text { participants open businesses. } \\
\text { Then, at Karang Harum Village } \\
\text { Library, there was a pipe } \\
\text { workshop training that can make } \\
\text { a person open a business after } \\
\text { attending the training. Deni, one } \\
\text { of the citizens in the village, } \\
\text { finally opened a business after } \\
\text { participating in that pipe } \\
\text { workshop. } \\
\text { Then, there was a massage } \\
\text { training at the library that } \\
\text { encouraged blind people to open } \\
\text { a massage business to help their } \\
\text { economy. Iman is a citizen of } \\
\text { Kendal, Central Java who was } \\
\text { inspired by the literacy for } \\
\text { prosperity concept, so that he } \\
\text { opened a massage service after } \\
\text { attending a massage training at } \\
\text { the Kendal Regency Public } \\
\text { Library. } \\
\text { Therefore, it is certainly more } \\
\text { than just applying for a job but } \\
\text { creating jobs /employment. }\end{array}$ \\
\hline
\end{tabular}

\section{Goal 10. Reduced Inequalities}

\author{
Indicator $\mathbf{1 0 . 2}$ - Social \\ inclusion and community \\ empowerment continues to \\ be enhanced, then \\ economic and political \\ inclusion for all, regardless \\ of age, gender, disabilities, \\ race, ethnicity, origin, \\ religion or economic ability, \\ or social, political, \\ economic, and other status \\ Indicator $\mathbf{1 0 . 3}$ - The \\ possibility of equal \\ opportunity and reducing \\ the gap between \\ communities, it includes \\ removing policies, laws, and \\ activities that lead to \\ discrimination, and \\ promoting policies related
}

a. The neutral and friendly space that makes learning environment accessible to everyone, including groups of displaced persons (potential to be socially excluded) such as migrants, refugees, minorities, indigenous peoples, and people with disabilities.

b. Equitable access to information that supports social, political, and economic inclusion
The concept of literacy for prosperity encourages all walks of life to be engaged in activities as well as facilities or services of public libraries that are partners of the National Library of Indonesia. As we have witnessed, many public libraries have policies related to discriminatory enforcement. The National Library of Indonesia has reviewed the impact of the program for those with low economy, those with disabilities, exemplary women at Sodong Village Library, Banten Province. Then at the Public Library of Kendal District, Central Java, there was a workshop that was only for the blind. Likewise, the Public Library of Magelang Regency provided a place to 


\begin{tabular}{ll}
\hline to discriminatory & carry out empowerment \\
enforcement. & activities for people with \\
& disabilities. Finally, they lead to \\
& strengthening their economy.
\end{tabular}

\section{Goal 17. Partnership for Goals}

\begin{tabular}{|c|c|c|}
\hline $\begin{array}{l}\text { Indicator 17.17- } \\
\text { Encouraging and improving } \\
\text { the cooperation of } \\
\text { government-private and } \\
\text { civil society effectively } \\
\text { based on experience and } \\
\text { sourced in cooperation } \\
\text { strategy. }\end{array}$ & $\begin{array}{l}\text { A global network of community- } \\
\text { based institutions, ready to } \\
\text { support local development plans }\end{array}$ & $\begin{array}{l}\text { The National Library of Indonesia } \\
\text { collaborates with many } \\
\text { stakeholders in realizing the } \\
\text { concept of literacy for prosperity } \\
\text { from both the government and } \\
\text { the private sector. The partners } \\
\text { are the National Development } \\
\text { Planning Board (BAPPENAS), the } \\
\text { Regional Development Planning } \\
\text { Board (BAPEDA), Office of } \\
\text { Community and Village } \\
\text { Empowerment, Office of } \\
\text { Communication and Informatics, } \\
\text { Office of Industry and Trade, and } \\
\text { others, such as the private } \\
\text { sector, colleges, NGOs/civil } \\
\text { society/community } \\
\text { organizations, private } \\
\text { companies, mass media, and } \\
\text { others. } \\
\text { Regarding regional stakeholders, } \\
\text { the examples that have been } \\
\text { described are the Ponorogo } \\
\text { Bukalapak Community and DPC } \\
\text { Pertuni in Kendal District. }\end{array}$ \\
\hline
\end{tabular}

From the table above, we can see that the National Library of Indonesia has implemented the literacy for prosperity to support the economic pillar in SDGs. The role of the National Library of Indonesia is in accordance with its duties which are described in Law No. 43 Year 2007 concerning Libraries (UU No. 43 tahun 2007 tentang Perpustakaan), namely conducting development, development, evaluation, and coordination of library management. In line with that, S.S said the following.

"We always make an annual report on the implementation of SDGs activities at the National Library and libraries in Indonesia and send it to IFLA. Also, we are planning a survey on the implementation of SDGs in provincial and Regency/city libraries in Indonesia"

This means that they are going to evaluate the development of literacy for prosperity that has been implemented at the public libraries to support SDGs. The National Library of Indonesia has also ensured the availability of lifelong learning facilities for public libraries to improve the economic condition of the community through literacy, as seen from the example described earlier. Regarding the economy, the latest data from the Central Bureau of Statistics (BPS) that were released in February 2020 show that the unemployment rate has decreased from February 2019 by $5.01 \%$ to $4.99 \%$. The unemployment decline is also one of the outermost concepts of literacy for prosperity, where they can eventually open a business or work after participating in a wide range of programs in public libraries.

Therefore, when the National Library of Indonesia supports the 3 objectives of the economic pillar that has been outlined, it will also affect the 3 social pillars mentioned by S.S. The concept of literacy for prosperity will ultimately alleviate poverty by providing a variety of trainings (goal 1), and then also by 
producing a quality education (goal 4). Education here also includes skills and eventually leads to healthy societies (goal 3).

\section{Realizing Social Inclusion through Literacy for Prosperity}

Regarding social inclusion, in the previous discussion about the $10^{\text {th }}$ goal of SDGs, Reduced Inequalities is one of the key points of literacy for prosperity. The National Library of Indonesia guarantees the public library as an open place for the prosperity of the society. This has an impact on the creation of an educational space in the form of knowledge and good skills so that the community will be prosperous inclusively.

In addition, the support contained in the $10^{\text {th }}$ goal of SDGs has an impact on other goals that are also supported by the National Library of Indonesia such as education and job creation so as to alleviate poverty. The discussion is in accordance with the indicator layers 10.2 and 10.3 in the resolutions of the United Nations. As explained in the previous example, the National Library of Indonesia has reviewed its impact on the diffable community, low-potential economic groups, and women.

The empowerment of the diffable community is carried out to create an inclusive area/city (Maftuhin, 2017). This will make them feel that they are part of the community and no longer worry about accessing public facilities such as libraries. Literacy-based empowerment is also done in low-potential or loweconomic conditions. This is in accordance with the initial concept of social inclusion described by Lenoir in $1975-1976$, which is poverty alleviation. This is certainly done by ensuring that the programs carried out by the National Library of Indonesia have an impact on job creation or getting employment, so that poverty can be resolved (also spelled out in the 8th goal of SDGs).

In the future, the National Library of the Republic of Indonesia is going to review again the impact of the concept of literacy for prosperity on the community and its role in the SDGs program. Studies are also conducted with attention to other potentially excluded communities because of, for example, racism, religion, and even HIV cases. There is a phenomenon that was reported by Bhaskara (2018), a reporter of Tirto, about a research conducted by the Indonesian National Commission on Human Rights, which recorded approximately 101 cases of ethnic and racial discrimination in the period $2011-2018$. The discrimination that occurred included the prohibition of public services, the rise of ethnicity or identity politics, the dissolution of traditional rituals, discrimination on land tenure rights for minority groups, and access to unjust employment. These can be studied in relation to the fact that public libraries are inclusive and safe places for all.

For people with HIV, this still sounds sensitive but it also needs to be considered how to empower them to achieve social inclusion. Iswati, Utami, \& Matahari (2017) stated in their research that they are not only disease-laden but also mentally induced by many people, so that public libraries as an inclusive place can empower them. The activities of HIV/PLWHA empowerment can be done in collaboration with related institutions. For example, Graha Mitra is an NGO (non-governmental organization) that focuses on empowering the HIV/PLWHA community (Yayasan Pelita IImu, 2018). Service for them requires people or institutions that genuinely care or are able to accept their condition (Tursilarini \& Hermawati, 2019). That is because usually they have learned the ins and outs of HIV sufferers and how they feel both physically and mentally.

Therefore, when all of these have been considered, a literate community will be realized in all levels of society without reeds. Communities will easily mingle and empower each other regardless of different groups because of race, ethnicity, religion, social and economic status, and even people with HIV. Public libraries can certainly be institutions that can create social cohesion for all levels of society by empowering them all. Finally, they can raise the level of their economic condition.

\section{Conclusion}

The paradigm shift makes literacy not the ability to read and write, but more than that the ability make something good from reading. Then this literacy can also be in the form of the ability to hear and understand information from other parties so that it can lead to action. The more literate society is, the more prosperous people are. The National Library of the Republic of Indonesia has an interest in adapting the concept of literacy for prosperity that was previously PerpuSeru program to build community welfare. 
The head of BAPPENAS for the 2016-2019 period also said that the literacy was instrumental in community development, one of which is alleviating poverty. Therefore, the National Library of Indonesia has built public libraries in Indonesia in order to provide benefits to the community in improving their standard of living, with the concept of literacy for prosperity. This is done by also using the concept of public libraries based on social inclusion to make it more open to all levels of society. The concept of literacy for prosperity places more emphasis on public libraries because it is a lifelong learning tool for all people.

Until now, many communities have prospered economically as the impact of the strengthening of literacy for prosperity by the National Library of the Republic of Indonesia in various public libraries. Some have succeeded in opening a business after simply reading books in the library, as experienced by Suprayetno (Deli Serdang) and Atok (Sekip Village). Then, some others have also opened their businesses after participating in a training or workshop in the library, such as Iman (Kendal), Deni (Bekasi), and Inor (Sukamara), so as the community in the Magelang Regency Public Library and others. All of them are the results of literacy improvement.

The concept of literacy for prosperity is also implemented to support the UN program, Sustainable Development Goals, one of which falls under the economic pillar. The objectives of the pillar supported in the UN program are goal 8 (Decent Work and Economic Growth), goal 10 (Reduced Inequalities), and goal 17 (Partnership for Goals). When these objectives have been supported, it will also eventually reach the 3 goals of the social pillar mentioned by the S.S., namely goal 1 (No Poverty), goal 3 (Quality Health), and goal 4 (Quality Education).

The National Library of the Republic Indonesia continues to build communities by implementing the concept of literacy for prosperity in public libraries that are partners in the Library Transformation Based on Social Inclusion. The National Library of Indonesia continues to conduct studies on the impact of implementing the concept of literacy for prosperity on people who have experienced benefits. This study can also be conducted on potentially excluded people such as victims of racial discrimination and HIV sufferers. This must be done to realize literate societies and economic empowerment for them.

\section{Acknowledgments}

I would like to say that I am grateful and be thankful to the Faculty of Letter, the State University of Malang that gives the research permit. Many thanks also to all my lecturers to educate and teach me all things about the Library, Information, and Cultural Science.

\section{References}

Adyannisa, V., \& Laksmi. (2018). Social Capital in the Daily Services of Depok City Public Library = Modal Sosial Dalam Keseharian Layanan Perpustakaan Umum Kota Depok. Edulib, 8(2), 205-221.

Afandi, T. (2018). Siaran pers: Seminar Nasional Literasi dan Pembangunan Sosial-Ekonomi. Retrieved from https://www.bi.go.id/id/ruang-media/siaran-pers/pages/sp_165814.aspx

ALEA. (2015). Literacy in 21st century Australia: the ALEA declaration. Retrieved from https://www.alea.edu.au/documents/item/1197

Badan Pusat Statistik. (2020). Keadaan Ketenagakerjaan Indonesia Februari 2020. Retrieved from https://www.bps.go.id/pressrelease/2020/05/05/1672/februari-2020--tingkat-pengangguranterbuka--tpt--sebesar-4-99-persen.html

Bappenas. (2019). Rancangan Teknokratik Rencana Pembangunan Jangka Menengah Nasional 2020 2024 : Indonesia Berpenghasilan Menengah - Tinggi Yang Sejahtera, Adil, dan Berkesinambungan. Kementerian PPN/ Bappenas, 313. https://doi.org/10.1017/CBO9781107415324.004

Bhaskara, I. L. A. (2018). Survei Komnas HAM: Diskriminasi Etnis \& Ras Masih Terus Ditolerir. Retrieved April 13, 2020, from Tirto website: https://tirto.id/survei-komnas-ham-diskriminasi-etnis-rasmasih-terus-ditolerir-dahP

Connaway, L. S., \& Powell, R. R. (2010). Basic research methods for librarians (5th ed.). Oxford: Libraries Unlimited.

Hariwijaya, M. (2016). Metodologi dan Penulisan Skrispi, Tesis, dan Disertasi untuk IImu Sosial dan Humaniora. Parama Ilmu: Yogyakarta.

IFLA. (2010). The mission and purposes of the public library. In C. Koontz \& B. Gubbin (Eds.), IFLA Public 
Library Service Guidelines (pp. 1-20). https://doi.org/10.1515/9783110232271.1

IFLA. (2016a). Access and Opportunity for all: How libraries contribute to the United Nations 2030 Agenda. IFLA Journal, 24. Retrieved from http://www.ifla.org/files/assets/hq/topics/librariesdevelopment/documents/access-and-opportunity-for-all.pdf

IFLA. (2016b). Libraries Can Drive Progress Across the Entire Un 2030 Agenda United Nations Sustainable Development Goals.

Iswati, R., Utami, S. B., \& Matahari, R. (2017). IbM Pemberdayaan kelompok dukungan sebaya (KDS) ODHA berdaya wujudkan kemandirian dan kesejahteraan. Media Komunikasi Dan Informasi Hasil Pengabdian Dan Pemberdayaan Masyarakat, 2(2).

Lawal, I. (2009). Library and Information Science Research in the 21st Century. Library and Information Science Research in the 21st Century. https://doi.org/10.1533/9781780630151

Maftuhin, A. (2017). Mendefinisikan Kota Inklusif: Asal-Usul, Teori Dan Indikator. Tataloka, 19(2), 93. https://doi.org/10.14710/tataloka.19.2.93-103

Mamik. (2015). Metodologi Kualitatif (N. Retnowati, Ed.). Sidoarjo: Zifatama Publisher.

Montoya, S. (2018). Defining literacy. In GAML Fifth Meeting. Hamburg: UNESCO.

Mustafa, Z. (2013). Mengurai variabel hingga insturmentasi. Yogyakarta: Graha Ilmu.

National Library of Colombia. (2017). Mobile libraries for peace. Retrieved October 31, 2019, from Library Map of The Worlds - SDGs Stories website: https://librarymap.ifla.org/stories/sdg/0/Country/Colombia

Pilgrim, J., \& Martinez, E. E. (2013). Defining Literacy in the 21st Century: A Guide to Terminology and Skills. Texas Journal of Literacy Education, 1(1), 60-69. Retrieved from http://www.texasreaders.org/volume-1.html

Rachmawati, I. N. (2007). Pengumpulan Data Dalam Penelitian Kualitatif: Wawancara. Jurnal Keperawatan Indonesia, 11(1), 35-40. https://doi.org/10.7454/jki.v11i1.184

Rawal, N. (2008). Social Inclusion and Exclusion: A Review. Dhaulagiri Journal of Sociology and Anthropology, 2, 161-180. https://doi.org/10.3126/dsaj.v2i0.1362

Safira, F. (2019). Peran Perpustakaan dalam Pemberdayaan Perempuan melalui Kegiatan Pelibatan Masyarakat di Perpustakaan Umum Kabupaten Malang. Jurnal Kepustakawanan Dan Masyarakat Membaca Vol., 35(1), 23-32.

Seftiawan, D. (2019). Literasi bukan hanya membaca. Retrieved June 9, 2020, from Pikiran Rakyat website: https://www.pikiran-rakyat.com/pendidikan/pr-01317946/literasi-bukan-hanya-membaca

Silver, H. (2015). The Contexts of Social Inclusion. SSRN Electronic Journal, (144). https://doi.org/10.2139/ssrn.2641272

Sterling Journal Advocate. (2016). Literacy is crucial to prosperity. Retrieved May 19, 2020, from Journal Advocate website: https://www.journal-advocate.com/2016/09/29/literacy-is-crucial-toprosperity/

Sugiyono. (2009). Metode Penelitian Kuantitatif, Kualitatif dan $R \& D$. Bandung: Alfabeta.

Sumekar, S., Salmubi, Perwitasari, Zen, Z., Wuryani, I., Siregar, A. R., ... Kismiyati, T. (2011). Standar Nasional Perpustakaan: bidang perpustakaan umum dan perpustakaan khusus. Jakarta: Perpustakaan Nasional Republik Indonesia.

Tursilarini, T. Y., \& Hermawati, I. (2019). Pendampingan Pekerja Sosial dalam Rehabilitasi Sosial Orang dengan HIV-AIDS = Social Workers Assistance in Social Rehabilitation of People Living With HIV-AIDS Tateki. Jurnal Penelitian Kesejahteraan Sosial, 18(2), 149-166. Retrieved from https://ejournal.kemsos.go.id/index.php/jpks/article/view/1805

Undang - Undang No. 43 Tahun 2007 tentang Perpustakaan. (2007). Retrieved from https://www.perpusnas.go.id/law-detail.php?lang=id\&id=170920114322Ir9g6HhRuc

UNDESA. (2016). Identifying social inclusion and exclusion. In Leaving no one behind: imperative on inclusive development. https://doi.org/10.18356/5890648c-en

United Nations. (2015). Transforming Our World: The 2030 Agenda For Sustainable Development A/Res/70/1. Retrieved from https://sustainabledevelopment.un.org/index.php?page=view\&type=111\&nr=8496\&menu=35

Vårheim, A., Steinmo, S., \& Ide, E. (2008). Do libraries matter? Public libraries and the creation of social capital. Journal of Documentation, 64(6), 877-892. https://doi.org/10.1108/00220410810912433

Warsilah, H. (2015). Pembangunan Inklusif Sebagai Upaya Mereduksi Eksklusi Sosial Perkotaan: Kasus Kelompok Marjinal di Kampung Semanggi, Solo, Jawa Tengah. Jurnal Masyarakat Dan Budaya, 17(2), 207-232. https://doi.org/10.14203/JMB.V17I2.283 
Yamin, M. (2018). Coca Cola Foundation Lepas Program PerpuSeru kepada Pemerintah. Retrieved June 24, 2020, from Sindonews website: https://nasional.sindonews.com/berita/1319606/15/coca-colafoundation-lepas-program-perpuseru-kepada-pemerintah

Yayasan Pelita IImu. (2018). Social enterpreneurship sebagai upaya pemberdayaan ODHA. Retrieved April 12, 2020, from Yayasan Pelita Ilmu website: http://ypi.or.id/social-enterpreneurship-sebagaiupaya-pemberdayaan-odha/ 